\title{
HNRNPA2B1 wt Allele
}

National Cancer Institute

\section{Source}

National Cancer Institute. HNRNPA2B1 wt Allele. NCI Thesaurus. Code C97497.

Human HNRNPA2B1 wild-type allele is located in the vicinity of 7p15 and is approximately $12 \mathrm{~kb}$ in length. This allele, which encodes heterogeneous nuclear ribonucleoproteins A2/B1, plays a role in both the processing and transport of mRNA.

Point mutations in the gene have been associated with ovarian serous carcinoma and medulloblastoma. 